\title{
Post hos nostra terra est: Mapping the Late Roman Ecumene with the Expositio totius mundi et gentium
}

\author{
Nikolas Hächler
}

This paper studies the landscape of the Late Roman ecumene as depicted by the Expositio totius mundiet gentium (Expos. mundi), ${ }^{1}$ written by an anonymous author in the middle of the 4th century CE. It will first contextualise the text and assess its structure, language and genre. The contribution will then focus on the distinction between Rome, the Sasanids and utopic societies in the east near Eden, the political and military organization of the Imperium Romanum as well as its economic framework and varying expressions of its culture. As this paper will show, the anonymous author does not present detailed descriptions of Rome's geographical landscape. Instead, the primary focus is on material resources of the Roman Empire, their potential for economic exploitation and the trading opportunities resulting from it. Rome's cultivated landscapes are thereby regarded as important preconditions for its success on an economic, political and cultural level.

Two Latin translations of a now lost Greek original are known (Fig. 14.1). ${ }^{2}$ The former is a slightly more elaborate account titled "Expositio totius mundi et

1 Expositio totius mundi et gentium, introduction, texte critique, traduction, notes et commentaire par J. Rougé (Paris 1966). A contribution by the author about the representation and functions of Roman cities in the Expos. mundi has been published in the journal Museum Helveticum under the title 'Et divites et omnibus bonis ornati sunt: The depiction of Roman Civitates in the Expositio Totius Mundi et Gentium in the middle of the 4th century CE.' Parts of the present findings - especially with regard to the edition and nature of the source text as well as considerations about its author - is treated there as well.

2 Fig. 14.1 based on Rougé 1966, op. cit. (n. 1), 104-118; 128-134; for the translations see ibid., 89-103 based on L. Hahn, Die Sprache der so genannten Expositio Totius Mundi et Gentium (Bayreuth 1898); A. Klotz, 'Über die Expositio totius mundi et gentium', Philologus 65 (1906), 97-127. Compare T. Sinko, 'Die Descriptio orbis terrae', Archiv für lateinische Lexikographie und Grammatik 13 (1904), 531-571; E. Wölfflin, 'Bemerkungen zu der Descriptio orbis', Archiv 


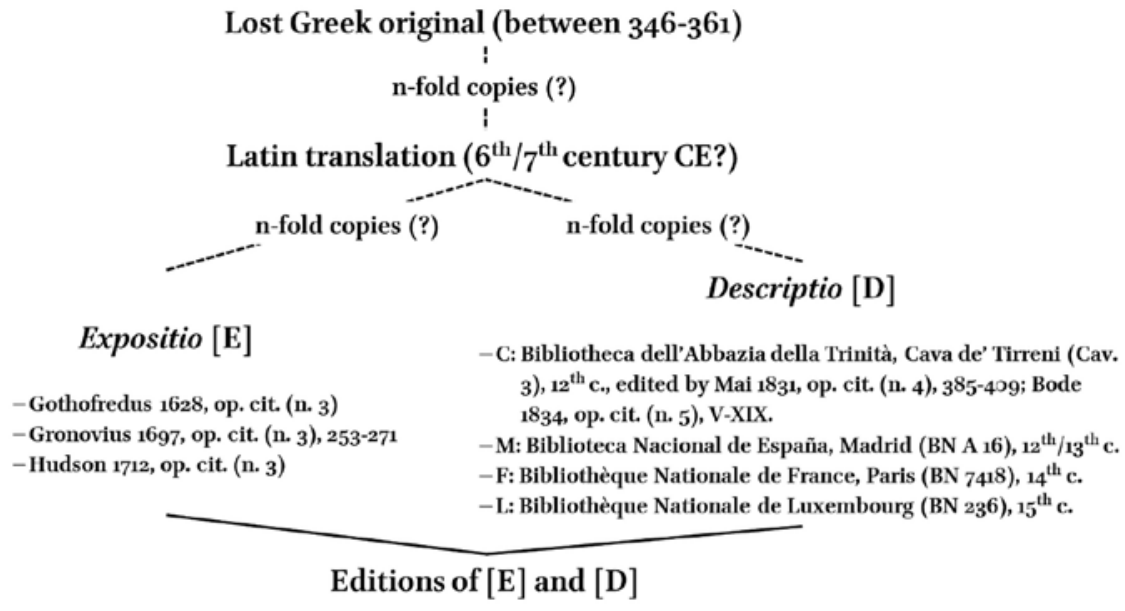

Expositio [E]

-Gothofredus 1628, op. cit. (n. 3)

-Gronovius 1697, op. cit. (n. 3), 253-271

-Hudson 1712, op. cit. (n. 3)

- C: Bibliotheca dell'Abbazia della Trinità, Cava de' Tirreni (Cav. 3), $12^{\text {th }}$ c., edited by Mai 1831 , op. cit. (n. 4), 385-409; Bode 1834, op. cit. (n. 5), V-XIX.

-M: Biblioteca Nacional de España, Madrid (BN A 16), $12^{\text {th }} / 13^{\text {th }}$ c. $-F$ : Bibliothèque Nationale de France, Paris (BN 7418), $14^{\text {th }} \mathrm{c}$.

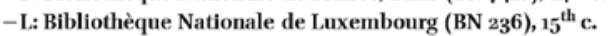

\section{Editions of [E] and [D]}

FIGURE 14.1 Schematic representation of the textual tradition

gentium" [E], first published in 1628 by J. Gothofredus under the title Vetus orbis descriptio, and then republished by J. Gronovius in 1697 and again by J. Hudson in $1712 .{ }^{3}$ The latter is a by comparison abridged version called "Descriptio totius mundi" [D], first brought to attention by A. Mai in 1831, based on a manuscript from the 12th century found in the "Cava de' Tirreni" (C: Cav. 3), ${ }^{4}$ and issued again by G.H. Bode in 1834 as well as in the "Geographi Graeci Minores" by K. Müller in 1861, who additionally considered another manuscript (F) for [D], written during the 14th century and preserved today in the "Bibliothèque Nationale de France" in Paris (BN 7418). Additionally, Müller presented an amended version of $[\mathrm{E}]$ together with his rendition of $[\mathrm{D}] .^{5}$ Both texts have subsequently been reprinted by A. Riese in the "Geographi Latini Minores" in

für lateinische Lexikographie und Grammatik 13 (1904), 574-578, who are convinced that the text was originally composed in Latin.

3 J. Gothofredus Vetus orbis descriptio (Paris 1628); J. Gronovius, Geographica antiqua (Leiden 1697), 253-271; J. Hudson, Geographiae veteris scriptores graeci minores III (Oxford 1712).

4 A. Mai, Classici auctores e Vaticanis codicibus editi III (Rome 1831), 385-409.

5 G.H. Bode, Scriptores rerum mythicarum latini tres Romae nuper reperti II (Paris 1834), V-XIX; K. Müller, Geographi graeci minores II (Paris 1861), XLIV-LI; 513-528. 
1878 with some smaller corrections. Thereafter, G. Lumbroso released two additional editions of the Expositio mundi in 1898 and 1903, followed by another one by T. Sinko in $1904 .{ }^{6}$ The last complete issue of both texts - accompanied by a French translation - has been presented by J. Rougé in 1966, who took a third manuscript (M) from the 12th/13th century into account for [D] as well, today treasured in the "Biblioteca Nacional de España" in Madrid (BN A 16). A final text $(\mathrm{L})$ from the $15^{\text {th }}$ century, accessible in the "Bibliothèque Nationale de Luxembourg" (BN 236), includes a transcript of the Descriptio [D], which has been analysed and edited by J. Rougé in 1973 as a supplement to his publication from $1966 .^{7}$ Other translations have been presented by A.A. Vasiliev in English, S.V. Poliakova and J.F. Felenkovskaia in Russian and H.-J. Drexhage in German. ${ }^{8}$

Although it is fortunate that the Expositio [E] and the Descriptio [D] have been preserved, one has to be aware of some uncertain factors due to their literary transmission: It is unclear how many versions of the now lost Greek text existed as well as whether and how frequently they were copied and distributed. We also do not know how much of the original has been lost or changed during that process. Furthermore, it is unaccounted for where and when exactly the Greek text has been translated into Latin. Hahn assumes that the document's transmission into Latin took place in Gaul; Sinko and Klotz propose the 7 th century as a terminus post quem for this process, Rougé, however, suggests that this has already happened during the 6th century. ${ }^{9}$

\section{$2 \quad$ Authorship, Structure and Genre}

All information about the Expositio mundi and its author has to be extracted from the document itself. According to text-immanent references, it has been

6 A. Riese, Geographi Latini Minores (Heilbronn 1878), 104-126; G. Lumbroso, 'Expositio totius mundi et gentium', Atti della reale Accademia dei Lincei, anno CCXCV (1898), 124-168; G. Lumbroso, Expositio totius mundi et gentium (Rome 1903); Sinko 1904, op. cit. (n. 2). See as well $R E$ 6,2 (1909), 1693-1694; Rougé 1966, op. cit. (n. 1), 89-91; 128-130.

7 J. Rougé, 'Une version gauloise de la 〈Descriptio totius mundi’', Scriptorium 27 (1973), 308-316.

8 A.A. Vasiliev, 'Expositio totius mundi: an anonymous geographic treatise of the fourth century A. D.' Seminarium Kondakovianum 8 (Prague 1936), 8-28; S.V. Poliakova, J.F. Felenkovskaia, 'Anonimnyi geografičskij traktat 〈Polnoje opisande vselennoj I naradov', Vizantijskij Vremenik 8 (1956), 277-305; H.-J. Drexhage, 'Die <Expositio totius Mundi et Gentium', MBAH 2 (1983), 3-41.

9 See Hahn 1898, op. cit. (n. 2), 82; Sinko 1904, op. cit. (n. 2), 537-538; Klotz 19o6, op. cit. (n. 2), 125-126; Rougé 1966, op. cit. (n. 1), 102. 
drafted between $346-361 .^{10}$ Since the writer presents a rather detailed account of Tyre, it seems probable that he lived on-site or was at least an inhabitant of a Syrian province. ${ }^{11}$ Even though we find biblical allusions in the preserved texts, ${ }^{12}$ the author was surely a pagan. ${ }^{13}$ His actual profession remains unknown. However, he appears to have been engaged in trade or to have been at least well-informed about commercial activities in the Roman world. ${ }^{14}$ At the beginning of the Expositio mundi, he briefly states the objectives and structural composition of his ambitious venture:

[D] §2: Since we desire to write, we must first of all determine [...] which peoples (gentes) were appointed from the east to the west; after that, how many barbarian nations (genera barbarorum) there are; thereupon, concerning all the land of the Romans (Romanorum terra), how many provinces there are in the whole world and what sort they are in respect to their wealth and power; what cities are found in each province; and what is remarkable in each province or city. Such a work seems to me fruitful and interesting for study. ${ }^{15}$

10 The texts alludes to the reign of Constantius II, who died on November 3361 , and his building activities in Seleucia in the year $346(\$ 28)$. For further discussions regarding the date of composition see Lumbroso 1904, op. cit. (n. 6), 5 (metà del secolo); Rougé, op. cit. (n. 1), 19 (359/36o); Drexhage 1983, op. cit. (n. 8), 4 (350 or 359/36o). Note that the author mentions the rebellious behavior of the inhabitants of Isauria (§45), which may refer to the plundering raids in the region around Seleucia around 35 o depicted by Amm. Marc. 14,2-8, ed. W. Seyfarth, Ammiani Marcellini Rerum gestarum libri qui supersunt (Leipzig 1978).

11 Vasiliev 1936, op. cit. (n. 8), 33; Rougé 1966, op. cit. (n. 1), 27-38; N. Pigulewskaja, Byzanz auf den Wegen nach Indien (Berlin and Amsterdam 1969), 47; 49-5o; T. Grüll, 'Expositio totius mundi et gentium', in Z. Csabai and T. Grüll (eds.), Studies in Economic and Social History of the Ancient Near East in Memory of Péter Vargyas (Budapest 2014), 633.

12 See $\S \S 2-4$. These references are considered as later interpolations only found in [D].

13 Rougé 1966, op. cit. (n. 1), 48-55; Grüll 2014, op. cit. (n. 11), 638-639; G. Marasco, 'L'expositio totius mundi et gentium e la politica religiosa di Costanzo II', AncSoc 27 (1996), 183-203. He repeatedly reports on important pagan places of worship in the text, but does not address church buildings or bishop's seats.

14 Rougé 1966, op. cit. (n. 1), 34; Drexhage 1983, op. cit. (n. 8), 4-6; C. Molè, 'Le tensioni dell'utopia. L'organizzazione dello spazio in alcuni testi tardoantichi', in M. Mazza and C. Giuffroda (eds.), Le trasformazioni della cultura nella tarda antichità. Atti del convegno tenuto a Catantia, Università degli studi, 27 sett.-2 ot. 1982 II (Rome 1985), 705; Grüll 2014, op. cit. (n. 11), 634-637 propose a variety of possible occupations, ranging from rhetor and sophist, (textile) merchant and entrepreneur to (literate) vir rusticus.

15 Translation by Vasiliev 1936, op. cit. (n. 8), 19 (with minor modifications), based on [D] §2: Quaerentes autem scribere, debemus dicere primum [...] quae gentes ab oriente usque ad occidentem constitutae sint; post hoc quanta sint genera barbarorum, deinde omnem 
After a short introduction $(\S \S 1-3)$, the author presents his readership with a description of the world beyond the eastern frontiers of the Roman Empire. He starts with the depiction of different fantastic/utopic communities near Eden and ends his portrayal with the Persian Empire (§§4-21)..$^{16}$ In the subsequent segment, he focuses on various locations within the Imperium Romanum (§§22-68). ${ }^{17}$ Whereas $\S \S 63-67$ feature Mediterranean islands, $\S 68$ concludes the Expositio mundi.

The text's emphasis on places of trade and merchandise, not unlike the Periplus Maris Erythrei from the 1st century CE, led Sinko to describe it as a product of "commercial geography" ("Handelsgeographie"). ${ }^{18}$ However, the unnamed author does not explicitly denote his writings as a geographical account, nor does he locate his oeuvre within a specific literary tradition. ${ }^{19}$ He presents many commercial centres within the Roman world but does not always state distances between possible emporia. In addition, he does not systematically indicate the value of traded goods. Since the text also contains some mistakes, ${ }^{20}$ the Expositio mundi in its current form would not have proven useful for merchants wishing to engage in trading activities within the Roman Empire.

Romanorum terram, quot sint in omni mundo provinciae, vel quales in substantia ac potestate; quae civitates in singulis provinciis habeant et quid in unaquaque provincia aut civitate possit esse praecipuum. Munificum enim hoc opus et studiosum mihi esse videtur.

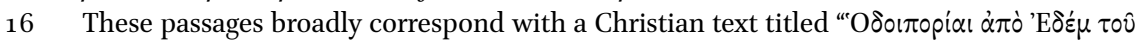
$\pi \alpha \rho \alpha \delta \varepsilon i \sigma o v ~ \alpha \chi \chi p l ~ \tau \omega \nu \nu ~ ' P \omega \mu \alpha i \omega \nu$ ”, edited with a French translation and a commentary by Rougé 1966, op. cit. (n. 1), 56-69; 350-355, which depicts the way from Eden to the Roman Empire.

17 The portrayal starts with Mesopotamia and continues with Syria, Egypt, Arabia, Asia Minor and Achaia, proceeds to the Dalmatian coast, followed by Italy, the Danube Region, Gaul, Spain and North Africa, see F.P. Mittag, 'Zu den Quellen der «Expositio totius mundi et gentium', Hermes 134 (2006), 344 for a non-technical map. It is remarkable that the author uses the terms "provincia" and "civitas" in a generalising manner to denote various types of regions and cities within the Roman Empire, see G. Traina, 'La prefazione alla Descriptio [Expositio] totius mundi', in C. Santini and N Scivoletto (eds.) Prefazioni, prologhi, proemi di opere tecnico-scientifiche latine III (Rome 1998), 61.

18 Sinko 1904, op. cit. (n. 2).

19 Apparently, he does not refer to specific geographical sources, for instance, by Eratosthenes, Herodotus, Ptolemy, Polybius, Posidonius, Diodorus, Strabo or Pliny the Elder. Regarding literary traditions in geographical writings see A. Podossinov, 'Die antiken Geographen über sich selbst und ihre Schriften', in M. Horster and C. Reitz (eds.), Antike Fachschriftsteller (Wiesbaden 2003), 91-103; J. Engels, 'Geography and history', in J. Marincola (ed.), A Companion to Greek and Roman Historiography (Oxford 2007), 542546; D. Dueck, Geographie in der antiken Welt (Darmstadt 2013), 29-80.

20 The province of Noricum and Italian Tuscia are depicted as cities $(\S \S 55 ; 57)$. The author misplaces Arabia $(\$ 38)$ and seems to be unaware of the Black Sea $(\S 45)$. 
These preliminary considerations leave open the question what the objective of this specific text might have been. I would like to argue that it revolves to a great extent around the demonstration of personal (geographical) knowledge and education. ${ }^{21}$ According to [D]'s introduction, we have to conclude that it was prima facie designed as an instructional summary for the education of the anonymous writer's son:

[D] §1: After all the advice (ammonitiones) that I have recommended to you concerning the conduct of your life (studium vitae tuae), my dearest son, I now wish to begin by telling you many wonderful stories (historiae plurimae et ammirabiles): some of them I have seen myself, others which I have heard from learned men, and some I have discovered by reading. Thus, by retaining them in your mind you will not only know many useful things but you will also succeed in adorning your wisdom (tuam ornare sapientiam) with varieties of such things. ${ }^{22}$

The author depicts himself as a learned and experienced man - even as a philosophus as indicated by [D]'s title -, perhaps in order to establish his own position among leading members of his home town by exhibiting his expertise in a renowned field of intellectual prowess. ${ }^{23}$ As is well known, the acquisition and the display of classical education $(\pi \alpha i \delta \varepsilon i \alpha)$ was an opportunity for social distinction. ${ }^{24}$ It therefore does not seem far-fetched to argue that the writer yearned to be perceived as an intellectual, despite or perhaps even because

21 The author's high regard for knowledge and education becomes apparent when one looks at his portrayal of the inhabitants of Berytus ( $\$ 25)$, who act as guardians of the provinces (custodes provinciarum) by interpreting the law as viri docti, as well as those of Egyptian Alexandria (§37), in qua invenitur plurima genera philosophorum. In the provinces of Paphlagonia et Pontus (\$44), we find rich, educated and highly distinguished men as well. Translation by Vasiliev 1936, op. cit. (n. 8), 19 (with minor modifications) based on [D] §1: Post omnes ammonitiones quas tibi commendavi de studio vitae tuae, carissime fili, incipiens nunc volo tibi exponere historias plurimas et ammirabiles quarum quidem aliquas vidi, ceteras vero ab eruditis auditu percepi, quasdam lectione didici. Haec igitur sensibus comprehendens non solum multa utilia cognoscebis, sed et tuam ornare sapientiam ex huiuscemodi rerum varietatibus praevalebis.

23 As pointed out by Str. 1.1.1, ed. S. Radt, Strabons Geographika, mit Übersetzung und Kommentar (Göttingen 2002-2011) geographical treatises were perceived as a part of practical philosophy. However, senators and knights did not necessarily write such texts themselves (Cic. Att. 2.4; 6-7, ed. H. Kasten, Atticus-Briefe - Epistulae ad Atticum [Berlin, Boston 2013, 3rd ed.]). In addition, the subject was considered to be rather difficult (Mela 1.1, ed. C. Frick, De chorographia libri tres [Stuttgart 1968, 2nd ed.]).

24 Regarding the social contexts of writers of specialised literature ("Fachliteratur") during the Principate, see M. Horster, 'Literarische Elite? Überlegungen zum sozialen Kontext 
he did not receive a classical formation. This thesis can be supported by an analysis of his use of language. ${ }^{25}$ Nonetheless, the text remains an impressive testimony indicating a perhaps not unusual intellectual phenomenon among viri humiliores after $300 \mathrm{CE}$, who possibly sought to distinguish themselves from their peers by means of literary production, thereby occasionally imitating members of the Roman Empire's socio-intellectual elite.

According to his own statements $(\S 1)$, the author relied on three types of sources, i.e. his own experiences, the stories and travel reports by learned people (eruditi) and documents he seemingly acquired himself. ${ }^{26}$ On the one hand, the writer's own experiences might have played the most important role in the comparatively detailed descriptions of cities within Syria and of Egyptian Alexandria. For many regions of Asia minor, on the other hand, he might have used the knowledge gained by interacting with travellers and merchants instead of relying on his personal experiences. For the Danube region, Gaul, Spain and North Africa as well as the eastern parts of the world, he appears to have reverted to his own education. ${ }^{27}$ This would explain why the depiction of these regions seems comparatively superficial.

\section{Characterisation of the Roman Landscape}

\subsection{Distinctions between Rome and the Eastern Realms}

The inhabited world is divided into three distinctive parts by the author of the Expositio mundi (Fig. 14.2). In the farthest regions of the East, near Eden, we encounter different utopic cultures $(\S \S 4-18)$. Further westwards, he locates the Persae and the Saraceni ( $\S \S_{1-20}$ ), followed by the regions, provinces and islands of the Roman Empire ( $\S 22-67)$. Both, the paradisiac cultures as well

lateinischer Fachschriftsteller in Republik und Kaiserzeit', in Horster and Reitz 2003, op. cit. (n. 19), 170-195.

25 See Rougé 1966, op. cit. (n. 1), 89-103. For an assessment of the source text's language see the author's contribution mentioned at the beginning of this paper.

26 In $\S 3$, he lists Moses (probably an interpolation from later periods), Berossus, Manetho, Flavius Josephus, Menander of Ephesus, Herodotus and Thucydides. Following §§42; 52; 61, he also read Homer and Vergil. F. Martelli, Introduzione alla "Expositio Totius Mundi". Analisi etnografica e tematiche politiche in un'opera anonima del IV secolo (Bologna 1982), 16; Mittag 2006, op. cit. (n. 17), 340-341 propose that the author might have included these intellectuals in order to appear more literate.

27 Regarding the dissemination of geographical knowledge in Late Antiquity see C. Krumeich, 'Schule. Elementar- und Grammatikunterricht Spätantike, in J. Christes, R. Klein and C. Lüth (eds.), Handbuch der Erziehung und Bildung in der Antike (Darmstadt 2006), 111-113; Dueck 2013, op. cit. (n. 19), 134-138. 


\begin{tabular}{|c|c|c|c|c|}
\hline \multicolumn{3}{|c|}{ Terra Romanorum $(\$ \S 22-67)$} & \multicolumn{2}{|c|}{ Terra Barbarorum $\left(\S_{4-20}\right)$} \\
\hline \multicolumn{3}{|c|}{$\lambda$} & \multicolumn{2}{|c|}{$\lambda$} \\
\hline $\begin{array}{l}\text { Mesopotamia } \\
(\$ 22) \\
\text { Osrhoene }(\$ 22) \\
\text { Syria }(\$ 23-32) \\
\text { Aegyptus }(\$ \$ 34- \\
37 ; 62) \\
\text { Arabia }(\$ 38) \\
\text { Cilicia }(\$ 39) \\
\text { Cappadocia }(\$ 40) \\
\text { Galatia }(\$ 41) \\
\text { Phrygia }(\$ 42) \\
\text { Armenia minor } \\
(\$ 43) \\
\text { Paphlagoniaet } \\
\text { Pontus }(\$ 44) \\
\text { Isauria }(\$ 45) \\
\text { Pamphylia }(\$ 45)\end{array}$ & $\begin{array}{l}\text { Lycia }(\$ 46) \\
\text { Caria }(\$ 47) \\
\text { Asia }(\$ 47) \\
\text { Hellespontus } \\
(\$ 48) \\
\text { Bithynia }(\$ 49) \\
\text { Thracia }(\$ 50) \\
\text { Macedonia }\left(\S_{51}\right) \\
) \text { Thessalia }(\$ 52) \\
\text { Graecia }(\$ 52) \\
\text { Achaia }(\$ 52) \\
\text { Laconia }(\$ 53) \\
\text { Epirus/Aetolia } \\
(\$ 53) \\
\text { Dalmatia }(\$ 53) \\
\text { Calabria }(\$ 53) \\
\text { Bruttium }(\$ 53)\end{array}$ & $\begin{array}{l}\text { Lucania }(\$ 53) \\
\text { Campania }(\$ 54) \\
\text { Italia }(\$ 55) \\
\text { Tuscia }(\$ \S 55[\mathrm{D}]- \\
56) \\
\text { Moesia et Dacia } \\
(\$ 57) \\
\text { Pamonia }(\$ 57) \\
\text { Gallia }(\$ 58) \\
\text { Hispania }(\$ 59) \\
\text { Mauretania }(\$ 60) \\
\text { Numidia }(\$ 60) \\
\text { Africa }(\$ 61) \\
\text { Aethiopia }(\$ 62) \\
\text { Pentapolis }(\$ 62) \\
\text { Libya }(\$ 62)\end{array}$ & Persae et Saraceni $(\$ \S 19-20)$ & 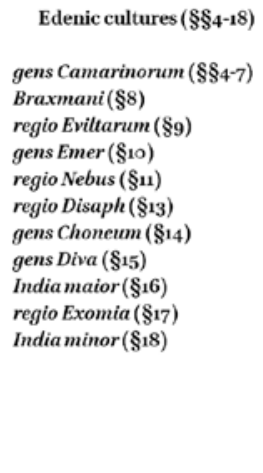 \\
\hline \multicolumn{5}{|l|}{ West $\leftarrow$} \\
\hline FIGURE 14.2 & $\begin{array}{l}\text { Schematic } \\
\text { author's de }\end{array}$ & 位 & iterramean island & $\begin{array}{l}\text { world (without the } \\
63-67 \text { ) }\end{array}$ \\
\hline
\end{tabular}

as the Sasanids and their allies stand in stark contrast to the Roman Empire and its landscape. In order to characterise the nature of the Edenic cultures, the following paragraphs will treat the gens Camarinorum as pars pro toto, ${ }^{28}$ because their description as an utopian society is the most extensive one and serves as a template for subsequent societies.

According to the Expositio mundi, the Camarini lead a blessed existence. Because they live near paradise, they appear completely freed from the need to work for food or clothing. Instead, they are provided with such items at regular intervals. Bread, for instance, repeatedly rains down from the sky like biblical manna (\$4). In addition to the fact that they do not have to take care of agricultural matters, the Camarini appear to be in possession of an abundance of natural resources. Of great interest to the author are deposits of valuable ores and gems, which they apparently mine themselves and which provide them with great wealth (§6). These goods, however, are not used for any commercial transactions. Because of nature's generosity as well as their natural felicity (felicitas), the Camarini refrain from emotional arguments $(\S 7)$. They govern themselves autonomously and do not need elaborate state structures. ${ }^{29}$ Besides that, they possess an extraordinary physical condition and are not affected by plagues $\left(\S_{5}\right)$. They even know the time of their own death and are therefore able to prepare themselves accordingly for their final moments $(\S 7)$.

28 The Indian city Camara appears as well in Peripl. Mar. Erythr. 6o, ed. L. Casson, The Periplus Maris Erythraei, Text with Introduction, Translation, and Commentary (Princeton 1989).

29 Martelli 1982, op. cit. (n. 26), 37-56; Molè 1985, op. cit. (n. 14), 731-733. 
It is remarkable that the landscape depicted by the Expositio mundi overall remains rather abstract and lacks specific geographical features (§6). It primarily serves as a stage for the depiction of the Camarini and their particular way of life.

It is within the society of Nebus further westwards that one finds governmental structures for the first time (\$11). Still farther in the west, we encounter communities which had to invent agricultural techniques in order to grow food (§12). The inhabitants of Axoum are depicted as brave in war and capable of defending the residents of India minor against the Persians (\$17). Approaching the Roman Empire, eastern cultures exhibit more and more aspects of sophisticated state systems, in relation to the production and distribution of food, self-government as well as the public organization of military power. Following the Expositio mundi, the conditions for communal life forms thus gradually become more inhospitable with increasing distance from Eden, so that societies require forms of self-government and agricultural techniques.

As mentioned before, the landscape itself does not play a major role within the passages alluded to. It is depicted as an ideal - albeit often vague - frame for utopic societies to live in. As such, it is not characterised in a tangible physical or geographical manner, e.g., by accurate depictions of mountain ranges or rivers. Thus, it remains an undetermined background for paradoxographical and ethnographical reports. According to the Expositio mundi, eastern societies near Eden are neither renowned for their constructional or commercial activities nor create impressive monuments nor are famous for their cities - notable features and accomplishments of societies of the Imperium Romanum -, since they do not need them in order to lead a prosperous life. The land apparently provides these communities miraculously with all the necessities without any need for physical labour, the invention of artisanal techniques nor the establishment of governmental structures.

In stark contrast to the usually peaceful utopian societies, the Persians are depicted as gruesome enemies of the Romans in rather stereotypical terms. Bold and strong in war, they are constantly attacking their neighbours. In addition, they commit incestuous acts (\$19) since they do not understand the dignity of nature (non cognoscentes dignitatem naturae)..$^{30}$ Just like their Persian neighbours, the Saraceni spend most of their lives waging war. Furthermore, they are impious (impii), perjuring (periuri) and unable to uphold oaths

30 The concept of human dignity bestowed upon humanity by nature was widely known in the Graeco-Roman world. Based on reason and freedom of will, it set men apart from animals, as expressed by Cic. off.1.106-107, ed. R. Nickel, Vom pflichtgemässen Handeln. De officiis (Berlin 2011, 2nd ed.). 
(sponsiones non custodientes). Finally, it is said that they are ruled by women, thereby subverting Roman ideals of government and gender (§20). As far as the anonymous writer is concerned, both the Persians and the Saracens are neither fond of agricultural nor of artisanal techniques. Instead, they are portrayed in a simplified manner as robbers, who sustain themselves by attacking wealthy communities like the Roman Empire. However, they appear to be in possession of many valuable goods, thus becoming precious trading partners of Roman merchants. ${ }^{31}$ Again, the geographical landscape is sketched in a rather superficial manner in the featured passages.

The portrayal of eastern cultures and the characterizations of the Persians and their allies contrast sharply with the way of life in the Imperium Romanum. While people near paradise do not have to work and lead a wondrously prosperous, independent and autonomous life, the Sasanids and the Saracens appear as a plundering force working against civilization. It is only within the Imperium Romanum where fruitful labour, peaceful commercial activities, sophisticated cultural achievements and balanced political rulership enable its inhabitants to live self-sufficiently. Furthermore, its abundant resources allow for a successful defence against the Persians, their allies, as well as other barbaric and often pillaging peoples around its borders, such as the Gothi (§58), the Sarmates ( $\$ 57)$, the Mazices (\$62) or the Aethiopii (\$62). The Roman landscape, impacted and formed by imperial structures of government, is thus clearly distanced from those communities mentioned on a political, military, economic and cultural level. Additionally, it appears to be the only place in the world where mankind realised the value of natural dignity. This stands in contrast with utopian societies, whose members lead lives full of godlike felicity, or the perverted ideals of the Persians, who behave like animals. This distinction is highlighted in the text's structure itself; the depiction of the Roman world is proudly introduced in [D] §22: Post hos nostra terra est.

\subsection{Landscape as Territory-Military and Political Organization of the Imperium Romanum}

The Roman ecumene is characterised by the terms "terra Romanorum" ( $\S 2$; 21-22), "omnis mundi provinciae" (\$2), "terra nostra" (\$\$21-22) and "orbis terrarum" ( $\S 23 ; 25 ; 31 ; 34)$. Its inhabitants are subject to the rule of two emperors, who organise the Roman territories with regard to political and military matters in particular. Although the Expositio mundi presents no detailed accounts of campaigns, it still considers martial realities to a certain extent. For instance,

31 See M. Raschke, 'New studies in Roman commerce with the east', in H. Temporini and W. Haase (eds.), ANRW 2.9 (Berlin and New York 1978), 677-679. 
we find sporadic references to armed disputes for strategically and economically important cities, which affected local trading activities in the context of the violent conflicts between the Sasanids and the Roman Empire under Constantius II ( $\$ 22)$. In this way, the document also refers to the existence of liminal spaces near the borders of Empire, where Roman dominion must be confirmed again and again against external threats, if necessary with military force. Additional conflicts at Rome's borders are hinted at in the depiction of Gaul $(\S 58)$.

As political and administrative centres, civitates play a fundamental role in the Expositio mundi, especially if they are treated as imperial residences. ${ }^{32}$ Syrian Antiochia is seen as an outstanding imperial domicile, overflowing with amenities and various people from all over the Empire (\$23). Besides Syria, Pannonia and Gallia play an important role in imperial politics as well (§57). Treveris features quite prominently as a central hub of military and economic activities in the region. Although the text does not clarify the policy of the residing ruler, the author of the Expositio mundi seems to be informed about the large number of soldiers stationed in Gaul as a defending force against the Germanic peoples. The text additionally mentions Thracian Heraclea as an imperial city, whereas Constantinople is given a surprisingly brief treatment $(\S 50)$. Finally, the emperors themselves actively shape the landscape of individual provinces and subsequently their mercantile activities. In order to provide his subjects with enough supplies and to improve trading conditions in general, Constantius II ordered the expansion of the harbour facilities of Seleucia in $346(\$ 28){ }^{33}$ Trading activities in Gaul overall appear to benefit from the presence of the ruler, although the prices of certain goods seem to be higher in comparison to the rest of the Roman Empire ( $\$ 58)$. In conclusion, the Expositio mundi characterises the Imperium Romanum on the whole as a very stable political and military entity around 350 , whose general prosperity does not seem to be affected by external aggressors at all.

32 An in-depth assessment of the role of various civitates as economic, political, military and cultural centres of the Roman Empire according to the Expositio mundi is provided by the author in the paper mentioned at the beginning of this contribution. This results in some recapitulations of the used examples with regard to the economic situation of the Roman ecumene as well as the depiction of cities as nodes of Roman culture.

33 It is noteworthy that the author mentions fiscal transports ( $\$ 28$ : onus fiscale) probably as part of the military annona to combat the Persians under Constantius II, as well as the distinction between public and private taxation (§28: fiscales species et privatas), see Rougé 1966, op. cit. (n. 1), 128; 248-249; W. Ball, Rome and the East (New York 2007, 3rd ed.), 157-159. 


\subsection{Connections between the Roman Landscape and the Economy of Empire}

While portraying economic aspects of the Imperium Romanum, the Expositio mundi primarily focuses on the role of cities. These are not depicted as separated entities, but share an important connection with their respective surrounding landscape. Fertile lands bring forth and sustain wealthy cities, as may be observed in the following cases: Syria (§33), thanks to its balanced climate, Egypt (§34), due to the Nile, Caria (§47), mainly because of its advantageous connections to the sea as well as the Hellespont (§48), Bithynia (§49), Thracia $(\S 50)$ and Italia $(\S 55)$ since they all provide the means for productive agricultural activities.

If there are no favourable climatic or geographical conditions, the population of provinces and subsequently cities must somehow adapt to these harsher conditions. Otherwise, they remain poor entities on an economical level in particular. In the case of Cappadocia, for instance, the cool climate does not allow similar farming practices (§40). Instead, the inhabitants had to invent new techniques (artificium) in order to adapt to the harsher weather conditions ( frigora maxima), ${ }^{34}$ leading the inhabitants of Caesarea to become specialists in the trade with furs and coats $(\S 40)$. The regions of Achaia, Graecia and Laconia present their denizens with comparable problems $\left(\$ 5^{2}\right)$. Because of their small dimensions and their mountainous character, there is not enough space for agricultural activities within the named regions. With the exception of Corinth, which is portrayed as a busy trading town, their value is, however, not primarily based on their commercial activities but on their famous history and their distinguished schools, specialised in the rhetoric arts (fama doctrinarum et orationum). There are, finally, regions that do not feature favourable physical characteristics or important cultural achievements, for instance the deserts of Libya ( $\$ 62)$. Contrary to Egypt, where the Nile brings agricultural abundance and economic growth $(\$ 36)$, the Libyan wastelands apparently lack such an advantage - it apparently rains only rarely there - and are therefore not known for their cultural or economic products. However, the author attests the inhabitants of the region a wise, pious and friendly character, which is considered as a divine gift in the environment of these harsh living conditions.

Although favorable climatic conditions and the general fertility are indeed an important factor for welfare in general, it does not guarantee commercial success per se. The text appears to present us with the implicit hypothesis that 
the production of and the trade in different goods is only possible through the access of the land's resources and their transformation through traditional agricultural customs and craftsmanship practised by the inhabitants of the Roman Empire. Cities play an important role in this regard since their inhabitants were mainly responsible for manufacturing various articles of trade. In certain cases, some towns specialised in fabricating unique goods, based on their natural resources and artisanal traditions. A telling example can be found in the creation of paper (charta) in Egyptian Alexandria (\$36). Their position on important trading routes further allows for an efficient exchange of goods; many of the urban dwellings mentioned in the Expositio mundi had access either to the sea or to a river. ${ }^{35}$ Thus, they form a dense mercantile network within the Roman Empire. Thanks to its port and the resulting accessibility, Arelatum easily receives all different kinds of items from all over the Roman Empire. From here, these goods are then distributed further North to the imperial residence in Treveris $(\$ 58)$. We find similar constellations in Syria. Here, Laodicia and Seleucia (\$28) actively support Antiochia through trading profits. In addition, Alexandria, Nisibis and Edessa provide the opportunity for further trade relations with foreign peoples $(\S \S 22 ; 34)$.

Regarding the landscape of the Roman ecumene in particular, it often seems to be reduced to its potential for commerce: on the one hand, the writer is mostly interested in the land's various resources, which in turn function as a material basis for the production of different commodities. On the other hand, he presents specific properties of the landscape with regard to the possibilities for trade with other urban centres. Overall, mercantile activities result in a homogenization of the Roman commercial landscape, thereby contributing to the consistent form of its political organisation and becoming an important basis for a unified Roman culture.

\subsection{Aspects of Roman Culture in the Context of Urban Landscapes}

When depicting aspects of the Roman way of life in the middle of the 4th century, the Expositio mundi focuses on the characterization of outstanding urban spaces and the thereby resulting cultural offerings for a town's inhabitants. Although the writer seems to be intrigued by imposing buildings, he does not depict these in a comprehensive manner. His selection of monumental structures appears to be quite eclectic as well. Nevertheless, his representation provides us with important information about the shape of the Roman cultural landscape on an urban level. 
The author presents two marvellous tetrapyla in Caesaraea and Bostra $(\S \S 26 ; 38) .{ }^{36}$ Alexandria is well-known for its museion and the temple of Serapis $(\S \S 34-35) \cdot{ }^{37}$ Additionally, there is a famous basilica in Nicomedia, which had to be rebuilt under Constantine I after a fire (§49). In Heraclea, a theatre as well as an imperial palace can be marvelled at $(\$ 50)$, since the emperor used the city as his imperial residence in 326 and 329 . Athens appears to possess a triumphal arch $\left(\$ 5_{2}\right)$ - perhaps a translator's misconception, who was not familiar with the acropolis, misconception. ${ }^{38}$ In Rhodes, visitors apparently spot the remains of the famous colossus after its destruction during an earthquake in $226 \mathrm{BCE}\left(\S_{6}\right){ }^{39}$ Finally, Rome's outstanding history is clearly reflected in its numerous monuments $(\S 55)$. The anonymous writer is especially astonished by the Circus Maximus in all its imperial glory.

It is worth pointing out that the author is a great advocate of circus games (ludi circenses). Again and again, amphitheatres in particular feature very prominently in the Expositio mundi..$^{40}{ }_{32}$ states different types of athletes and artists from Syrian urban settlements, providing important opportunities for spectacular shows: Tyre displays the best actors, Caesarea features prominent pantomimes and Laodicia brings forth the most talented charioteers in the world. The wrestlers of Ascalon appear always victorious and the rhetors of Gaza are apparently able to convince even their most stubborn opponents. The same town exhibits excellent fighters in vicious pankration-contests as well. Heliopolis and Castabala, on the other hand, present more peaceful flautists and trapezists. The author's interests also include pagan cults. He appears to be quite impressed by the adoration of Venus in Heliopolis ( $\$ 30)$, thus referring to the cult of the dea Syria described by Lucian; ${ }^{41}$ in Rome he is amazed

$36 \quad$ Note that J. Mühlenbrock, Tetrapylon (Münster 2003) does not mention tetrapyla in Arabia.

37 See C. Haas, Alexandria in Late Antiquity (Baltimore and London 1997), 146-148; R. Bagnall, 'Alexandria: library of dreams', Proceedings of the American Philosophical Society 146 (2002), 257-262; H.-G. Nesselrath, 'Das Museion und die Grosse Bibliothek von Alexandria', in T. Georges, F. Albrecht and R. Feldmeier (eds.), Alexandria (Tübingen 2013), 65-9o.

$38 \quad$ Rougé 1966, op. cit. (n. 1), 292.

39 Regarding this wonder of the ancient world see U. Vedder, Der Koloss von Rhodos (Mainz 2015).

40 Repeatedly, the author mentions amphitheaters in Antiochia, Laodicia, Tyre, Berytus, Caesaraea, Nicomedia, Gortyna and Syracuse. He highlights the ludi circenses additionally in Constantinople $\left(\S 5^{\circ}\right)$. Further references are to be found in the description of Corinth $\left(\S^{2}\right)$ and Carthage $(\S 61)$.

41 Luc. Syr.D., ed. J.L. Lightfoot, On the Syrian Goddess (Oxford 2003). 
by the cult of Vesta $(\S 55)$. People pray to Serapis in Alexandria (§37) where the Expositio mundi also locates centres for philosophy and medicine.

Finally, the author occasionally presents his readership with aspects of cultural geography, i.e. depictions of the landscape together with its (often religious) history. Alexandria is presented as the chosen city of Asclepius (§37) and in Cyzicus the deity Venus is said to have bestowed her beauty on all women with Cupid's arrows $(\S 48$, only in [E]). In describing Achaia the author mentions Mount Olympus, considered as the seat of the gods $(\S 52)$, in Carthage he recalls the trickery of Dido during the founding of the city described by Virgil ( $(61)$. When depicting Tuscia ( $\left.\S \S 55^{-}-56\right)$, he reminds his readers that the origin of the art of divination (haruspicia) is to be found there. Among the Cyclades, finally, Delos is highlighted in particular because of the associated myth about the birth of the deities Diana and Apollo (\$63). Such accounts are comparable to anecdotes, for instance, found in Strabo, who often enriched his geographical descriptions with historical, mythological or even paradoxographical references, thereby further shaping the image of the Roman ecumene in space and time.

In addition to the political and economic interconnectedness of the Roman Empire the author records various manifestations of a highly unified Roman culture throughout the Mediterranean. Local differences between individual provinces, regions and cities still exist and are usually presented as specific achievements, advantages and benefits over others or highlighted as remarkable peculiarities. However, it is ultimately the interconnected relationship of all these individual cultural landscapes with each other that creates a comprehensively Roman modus vivendi.

The Roman ecumene is portrayed as a very prosperous entity by the Expositio mundi. Its landscape is essentially characterised by the relations between the (fertile) land and its (adaptive and versatile) inhabitants, the interconnectivity of economic and cultural hubs and a strong mainstream culture linking far apart regions to form one coherent Roman landscape. These developments are enabled by distinct political structures headed by two emperors, who continually organise provinces and cities. Thus, they order the land as well as its resources as a whole, in order to keep up the continuous existence of the Empire while fighting against foreign forces. The landscape is often reduced to its productive possibilities and commercial prospects. The unnamed writer is 
not so much interested in the geographical components of different regions thereby generally omitting typical landmarks such as mountain ranges, rivers or valleys - but in the general possibilities of agricultural and artisanal production, the latter usually located in greater cities within individual provinciae. Because all regions, provinces, and cities are connected to each other due to political structures, trading routes, and cultural habits, the political, economic and cultural landscape of the Roman ecumene takes a rather homogenous and unified shape. Ultimately, all regions profit from each province's individual contributions.

In addition, the Expositio mundi compares the structure, organisation and functionality of the Imperium Romanum with other communities inhabiting the world. In contrast to the Persians and the Saraceni, who are depicted as reprehensible, but wealthy societies, the Roman Empire does not wage war against its neighbours, but uses its resources to successfully defend itself against incoming attacks. In comparison with utopic societies, inhabitants of the Roman world lack the advantages of miraculous generation of food, longevity or immunity to maladies. Furthermore, its inhabitants are in need of governmental structures in order to lead a peaceful communal life. Thanks to the application of reasonable planning and purposeful work, however, Roman societies are able to adapt to their landscape in the western parts of the world, thus mirroring the fortunate existence of Edenic cultures at least to a certain extent. While peoples like the Camarini automatically led prosperous lives due to their place of residence near paradise, the inhabitants of the Rome Empire, however, had to actively deal with and learn about their landscape over time, thereby laying the foundation for their own existence far beyond Eden. 


\section{Appendix: Depiction of Utopian Cultures}

\begin{tabular}{|c|c|c|c|}
\hline Paragraph & People & Moral qualities/cultural habits & $\begin{array}{l}\text { Lifestyle/material } \\
\text { resources }\end{array}$ \\
\hline $4-7 ; 12$ & $\begin{array}{l}\text { gens } \\
\text { Camarinorum }\end{array}$ & $\begin{aligned} \text { - } & \text { Very pious } \\
\text { - } & \text { Do not get emotional or } \\
& \text { judgmental } \\
\text { - } & \text { Blessed in body and soul } \\
\text { - } & \text { Require no form of government } \\
\text { - } & \text { Do not get sick and usually die } \\
& \text { between } 118-120 \text { years of age } \\
\text { - } & \text { Know the date of their death }\end{aligned}$ & $\begin{array}{l}\text { - Do not have to labour, } \\
\text { since bread rains daily } \\
\text { from the sky } \\
\text { - Drink a beverage mixed } \\
\text { with honey and pepper } \\
\text { - } \text { In possession of precious } \\
\text { clothes which do not get } \\
\text { dirty by normal means } \\
\text { and may be purified by } \\
\text { fire } \\
\text { - In possession of precious } \\
\text { gems }\end{array}$ \\
\hline 8 & Braxmani & $\begin{array}{l}\text { - Lead a prosperous and fulfilled } \\
\text { life } \\
\text { - Do not need any form of } \\
\text { government }\end{array}$ & $\begin{array}{l}\text { - In possession of } \\
\text { similar goods like their } \\
\text { neighbours } \\
\text { - Eat fruit (pomis), pep- } \\
\text { per (pipere) and honey } \\
\text { (melle) }\end{array}$ \\
\hline 9 & regio Eviltarum & $\begin{array}{l}\text { - Lead a prosperous and fulfilled } \\
\text { life } \\
\text { - Do not need any form of } \\
\text { government }\end{array}$ & $\begin{array}{l}\text { - Eat fruit (pomis), pep- } \\
\text { per (pipere) and honey } \\
\text { (melle }\end{array}$ \\
\hline 10 & gens Emer & $\begin{array}{l}\text { - Lead a prosperous and fulfilled } \\
\text { life } \\
\text { - Do not need any form of } \\
\text { government }\end{array}$ & $\begin{array}{l}\text { - Eat fruit (pomis), pep- } \\
\text { per (pipere) and honey } \\
(\text { melle })\end{array}$ \\
\hline 11 & regio Nebus & $\begin{array}{l}\text { - First governmental structures } \\
\quad \text { (regitur a maioribus) }\end{array}$ & $\begin{array}{l}\text { - Eat fruit (pomis), pep- } \\
\text { per (pipere) and honey } \\
\text { (melle) }\end{array}$ \\
\hline 13 & regio Disaph & $\begin{array}{l}\text { - Well governed } \\
\text { - Morally righteous }\end{array}$ & \\
\hline 14 & gens Choneum & $\begin{array}{l}\text { - Well governed } \\
\text { - } \text { Morally righteous }\end{array}$ & \\
\hline
\end{tabular}


(cont.)

$\begin{array}{lll}\text { Paragraph People Moral qualities/cultural habits } & \begin{array}{l}\text { Lifestyle/material } \\ \text { resources }\end{array}\end{array}$

15

16

$$
\begin{array}{ll}
\text { gens Diva } & - \text { Well governed } \\
\text { India maior } & - \text { Morally righteous } \\
& - \text { Well governed } \\
& - \text { Morally righteous }
\end{array}
$$

17

18
India minor
regio Exomia - Well governed
- Morally righteous
- Potent in war
- Well governed

- Deal in all kinds of commerce and function as a hub-point between western and eastern societies

- In possession of many elephants 